\title{
MATHEMATICAL ASSOCIATION
}

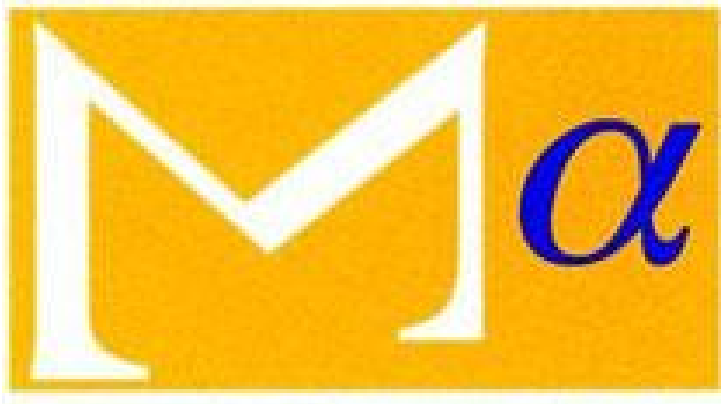

\section{supporting mathematics in education}

The Aim and Methods of School Algebra. 1. The Aim of Algebra Teaching Author(s): T. P. Nunn

Source: The Mathematical Gazette, Vol. 6, No. 95 (Dec., 1911), pp. 167-172

Published by: The Mathematical Association

Stable URL: http://www.jstor.org/stable/3602844

Accessed: 22-06-2016 04:51 UTC

Your use of the JSTOR archive indicates your acceptance of the Terms \& Conditions of Use, available at

http://about.jstor.org/terms

JSTOR is a not-for-profit service that helps scholars, researchers, and students discover, use, and build upon a wide range of content in a trusted digital archive. We use information technology and tools to increase productivity and facilitate new forms of scholarship. For more information about JSTOR, please contact support@jstor.org.

The Mathematical Association is collaborating with JSTOR to digitize, preserve and extend access to The Mathematical Gazette 


\title{
THE
}

\section{MATHEMATICAL GAZETTE.}

\author{
EDITED BY
}

W. J. GREENSTREET, M.A.

WITH THE CO-OPERATION OF

F. S. MACAULAY, M.A., D.Sc.; ProF. H. W. LLOYD-TANNER, M. A., D.Sc., F.R.S.;

Prof. E. T. WHITTAKER, M.A., F.R.S.

LONDON :

G. BELL AND SONS, LTD., PORTUGAL STREET, KINGSWAY, AND BONBAY.

\begin{tabular}{llc}
\hline Vol. VI. & DECEMBeR, 1911. & No. 95. \\
\hline
\end{tabular}

\section{INTERNATIONAL CONGRESS OF MATHEMATICIANS,} 1912.

The Mathematical Association, have undertaken to organise an exhibit, illustrative of Mathematical Education in Great Britain, for the Educational Section of the forthcoming International Congress of Mathematicians, to be held at Cambridge in 1912. It is specially desired to obtain specimens of ordinary mathematical work, both good and average, in various types of schools, as well as models and diagrams. All those willing to co-operate are requested to communicate with the Hon. Secretary of the Exhibition Committee, P. Аввотт, Esq., Wildwood, West View, Highgate.

\section{THE AIM AND METHODS OF SCHOOL ALGEBRA. ${ }^{1}$}

\section{THE AIM OF ALGEBRA TEACHING.}

$\S 1$. Definition of aim. A distinguished psychologist recently addressed a body of our American colleagues on the teaching of physics. "Your aim in the teaching of physics," he told them, "should be-to teach physics." The advice was excellent-especially from one who is apt to be regarded as an intellectual Strong Man, full of esoteric knowledge about the development of mental muscle. Substituting "mathematics" for "physics" we may well adopt the maxim with all its implications, negative and positive.

$\$ 2$. Negative implications. Beginning with the negative implications our amendment of Prof. Baldwin's dictum may be expanded as follows. In the first place, the central purpose in teaching mathematics is not to "train the power" of reasoning, of generalising, of "mental accuracy," etc. The fallacies embodied in the persistent heresy of "formal training". have been repeatedly exposed, and need not detain us here. The time should soon couve when an educational writer may ignore them. The chemist does not feel bound to begin his text-book by rebutting the phlogiston-theory, nor the geographer to demolish the sophistries of the flat-earthers.

In the second place, its direct usefulness in after-life cannot be given as a sufficient reason for universal instruction in mathematics. As a matter of

1 These articles contain the substance of the two introductory lectures of a course on Algebra in the Secondary School first given at the London Day Training College in the Michaelmas term of 1909 and repeated in 1910. 
fact, few of our pupils will need more than a sound knowledge of the multiplication table, the power to check "change" readily, and the ability to keep simple accounts. The argument for carrying the pupil's mathematical learning beyond this point which says that "you never know that it won't some day be useful to you " would lead, if it were taken seriously, to a curriculum of grotesque composition and gigantic proportions. On the other hand, the imposition of an elaborate course of instruction upon a whole school, because a sprinkling of engineers and university scholars ${ }^{1}$ may need it in after-life, is a plan obviously unscientific and almost certainly unjust. The universal opinion that every one ought to learn mathematics must have some better justification than this.

\$3. Positive implications. Interpreted positively our dictum supplies this justification by an assertion as simple as it is bold. Mathematics is to be taught, not because the knowledge is necessary for the acquisition of something else, but because it is itself a desirable possession. Mathematics is, like literature and art, a specific form of fine human achievement, one of the cardinal modes in which man has "found himself" and expressed his possibilities. The person who studies it in the right spirit offers himself to one of the great influences that have moulded modern civilisation. For, like St. Paul's Cathedral, the edifice of mathematics is at once its architects' monument and a perennial means of spiritual expansion. In this doctrine is to be found the only ground for teaching mathematics universally that can be held against hostile criticism. It is the ground upon which all the essential subjects of the curriculum must alike make their defence. They represent modes of human activity, intrinsically of such worth, historically of such significance, that every person to be fully educated must have entered into them, at least so far as to acquire a sympathetic acquaintance with their character. Nil humanum a me alienum.

\$4. Mathematics an activity. The point of immediate inportance here is that mathematics is conceived not as a static body of "truths" but in the dynamic form of an activity. In history mathematics has obviously been an activity, pursued continuously through the generations, and becoming, after the manner of all sustained human activities, more definite in its form, more exteusive in its range, more complex in its structure from age to age. To teach mathematics should be to reproduce in the school-as far as the conventional conditions of school life and "the naturally inferior state of boyhood" permit-the essential features of this historic activity.

So much admitted, a two-fold inquiry opens before us. Human activity is always put into movement by mental forces called motives. In the first place, then, what are the motives or springs of activity that have generated mathematics in history? In the second place, how far are these motives operative in the immature mind of the schoolboy? For it is evident that if we cannot appeal to the same motives, we cannot really reproduce in him the same activity - we can only force him into a useless simulation of it.

$\$ 5$. Mathematical motives in history. Human motives are, proverbially, mixed, and any attempt to separate them for the sake of clearness, runs the risk of falsification. Remembering this danger we may still admit in mathematics and science three sufficiently distinct types of intellectual activity, each dominated by a special motive. ${ }^{2}$ In the first type the dominating motive is simple wonder-the mind's reaction to and pursuit of

\footnotetext{
${ }^{1}$ It is difficult to bring girls in at all unless in this category !

2 These distinctions were first developed by the present writer in an article on Science Teaching in Adamson's Practice of Instruction (1906). He described them subsequently in an address on Nature Stucly given to the L.C.C. Conference of Teachers, Jan. 1907, and in a paper on Epistemological Levels in the Proc. of the Aristotelian Society, 1907-8 (cf. Hodson, Broud Lines in Science Teaching, 1909, Ch. VI.) They are professedly based on observation, but the philosophical reader will note the parallel with the Hegelian triad, "Thing, Law, System."
} 
the thing that is novel or striking in itself. The fact that if $a^{2}+b^{2}=c^{2}$ the triangle with sides $a, b$ and $c$ will be right-angled is a mathematical example of this kind of thing. To understand the discovery (as distinguished from the demonstration) of this truth we need suppose no other motive at work than simple wonder. The discovery of the rule of succession of the coefficients in a binomial expansion (when the index is a positive integer) is another example." Most of the sciences begin in this way-"science is the child of wonder," said Plato. The mystical or superstitious attitude towards the properties of numbers which we associate with the Pythagoreans and the mediaeval magicians is largely an expression of this fact. The early history of equations-originating in mathematical conundrums-tells the same tale.

In the second type the attraction of the novel and curious may still be present, but it is displaced from its position as the central motive. That position is occupied by the motive of utility. A century or so ago the science of electricity began by delighting our forefathers with pretty discharge phenomena, thrilling "shocks" and weird movements in frogs' legs. But it passed from this stage to produce the lightning conductor and the electric telegraph for the service of man's serious ends. A similar transition occurred in the field of mathematics when, before the dawn of history, some inspired cave-dweller first thought of using pebbles as tallies for business purposes. The documents of the science, from the Rhind papyrus (which tells how the Egyptian priests surveyed the lands left dry by the Nile) down to Prof. Karl Pearson's latest paper on the theory of statistics, give innumerable illustrations of mathematical activity dominated by the motive of utility.

In the third place utility in its turn takes with simple wonder a subordinate place. Reverting for illustration to the science of electricity we have now the stage represented by the work of Clerk Maxwell rather than the work of Wheatstone. The central motive is the systematising motive-the impulse to bring some entire province of inquiry under the sway of a body of clearly outlined and closely articulated ideas. Though the consequences of scientific activity on this plane are often both wonderful and useful-like wireless telegraphy, which followed directly from Maxwell's theoretical investigations-yet such consequences are, properly speaking, only byeproducts of a process which in itself seeks none of them. Its real aim is indicated by the oft-quoted toast of the savants who drank "to the next great scientific discovery, and may it never be of any use to anybody!"

In mathematics Euclid's Elements of Geometry affords the best known example of this stage. Euclid's aim was not to make a collection of the most interesting properties of figures, nor to write a handbook for the practical man. Taking a large number of striking or useful geometrical propositions, his aim was to weave them into a logical whole. In other words, he was interested not so directly in presenting the truths themselves as in developing the logical nexus between them, so that geometry as it left his hands might have the highest characteristics of a rational science. Prof.

1 Set down a column of units. Construct a second column by adding each figure in the first column to the figure to the right of it, and setting the sum beneath the latter. Construct the third, fourth, etc., columns in the same way. The result is the following table ("Pascal's Numbers") :

$$
\begin{array}{rrrrrrr}
1 & & & & & & \\
1 & 1 & & & & & \\
1 & 2 & 1 & & & & \\
1 & 3 & 3 & 1 & & & \\
1 & 4 & 6 & 4 & 1 & & \\
1 & 5 & 10 & 10 & 5 & 1 & \\
1 & 6 & 15 & 20 & 15 & 6 & 1 \\
& \multicolumn{7}{c}{\text { etc., etc. }} & &
\end{array}
$$


Chrystal's well-known work on algebra exhibits the same motive at work in the province to which this book belongs. Such a work as Dr. Whitehead and Mr. Bertrand Russell's Principia Mathematica shows the rationalising impulse in its present form, freed as entirely as may be from the elements of utility and wonder. ${ }^{1}$

\$6. The motives during the school age. Turning now to the schoolboy, there can be no doubt that he is accessible to the intrinsic wonderfulness of some mathematical facts-for example, that the angle in a semicircle is always a right angle, that the sum of the first $n$ odd numbers is $n^{2}$. Most readers can probably remember in themselves a "wonder" attitude towards numbers and their relations-magic squares, the counting into many thousands, "think of a number" riddles, etc.-an attitude which preceded any real appreciation of the usefulness of calculation. It is possible that the performances of "calculating boys" are due in part to an exceptional development of this attitude. It is unfortunate that the puritanical traditions of the mathematical curriculum have led to the neglect of the "wonder stage." Its due cultivation would doubtless have a happy effect upon the pupil's subsequent progress.

The interest of the utility motive is, as far as the secondary school is concerned, much better marked, much more persistent and much more important. In science and mathematics it seems to dominate the boy's natural intellectual activity, at least up to the age of 15 or 16, and is powerful far beyond that period. That is to say, during the greater part of his school life he is prone to value a scientific or mathematical truth less for its "beauty," and less for the part it plays in a deductive system, than for its usefulness in application. To a schoolboy once known to the writer algebra was a dark and rather unpleasant mystery until inquiries made (out of school) about an extremely simple equation in a handbook on astronomy brought to light the exciting results that could be deduced by algebra from observations of the planetary movements. A year or so later he had taught himself, with the aid of Chambers' Tables and Orr's Circle of the Sciences (Art. "Nautical Astronomy"), to use seven-figure logarithms and the formulae of spheridal trigonometry, so as to check the alleged latitude of his home and the accuracy of the town clock.

Such examples - to which every reader of this article could doubtless contribute-bring out a point of great importance. The mysterious impulse which makes every little boy and girl spend Jong hours in "make-believe" play is not exhausted during childhood. It persists long afterwards in subtler and more intellectualised forms, which still serve Nature's purpose of making the youth experiment in imagination with life as a preparation for the serious business of living it. ${ }^{2}$ The Boy Scout movement has shown us how much intellectual and moral energy this impulse can set in motion in the most unromantic boy. The schoolmaster will do well to capture it for his purposes also.

The rationalising or systematising motive-as defined in $\$ 5$-plays an inconspicuous part before the age of 16 , and in many boys has never really an independent existence at all. A stimulating teacher may awaken it to a considerable degree of vigour here and there, but his ability would in most cases be better directed to developing the prissibilities of the utilitarian motive which exists in every boy. The cause of many of our present discontents is that we persist in regarding as the whole of mathematics what is really only the terminal stage of a process of development-a stage which

1 This statement is not meant as a prophecy that no useful results will follow from the labours of these mathematicians. History has often shown the precariousness of such predictions. The statement concerns merely the motives to be assumed behind the intellectual activity that produced the book.

2 Cf. Karl Gross, The Play of Man, and McDougall, Social Psychology, Ch. IV. 
many of our pupils never reach. Here is the psychological principle which justified "the dethronement of Euclid" and other reforms that owe so much to the eloquence, wit, and authority of Prof. Perry.

$\S 7$. Applications to algebra. The foregoing argument affects very definitely the question of the proper aim of algebra teaching. It is possible to form two very different but equally detinite conceptions of it. According to the one, algebra is an independent science in the same sense as the geometry of Euclid's Elements is a science. That is, it is a deductive system of truths based upon and developed from a small number of definitions and fundamental laws or axioms. ${ }^{1}$ Prof. Chrystal's work has already been quoted as embodying this conception of algebra. The results obtained in such a deductive investigation may have important applications outside its borders, but it is, strictly speaking, no part of the business of the teacher of the science to consider them. If he does so, it is either as a tribute to their extra-scolaire importance or "to lend interest" to his own treatmenr.

According to the other conception, the very existence of algebra and the form which its development takes, are determined by these practical applications. Algebra is a collection of tools to be forged one by one as they are required to deal with problems presented by the physical or social world; a symbolic language specially designed for the exploration and description of phenomena in their numerical aspects.

If the doctrine of $\S 6$ is well founded, these two views do not mutually exclude one ancther from the curriculum. For each corresponds to a definite type of mathematical activity as we find it in history. But there is the important difference that the second conception implies the utilitarian motive, which is practically universal during the school age, while the former implies the rationalising motive, which has no notable development until the end of the school period, and then only in comparatively few boys and girls.

The second conception should, then, be the teacher's guide in his dealings with the general body of his pupils. The former is relevant chiefly to the needs of the "specialist," and then only after he has traversed with his fellows the ground covered by the utilitarian conception. For, historically and logically, the systematising stage is essentially not a stage of discovery, but consists chiefly in the organisation of results gained on lower planes of intellectual activity. It follows that even the boy of strong rationalising bent will do well not to miss a point of view from which his studies will gain a vitality which the cloistral pursuit of a pure science cannot itself supply.

\$. Interest and discipline. To say that in teaching we must consider the natural springs of intellectual activity is to enunciate the modern "doctrine of interest." 2 This doctrine is often worst served by those who proclaim themselves its chief friends. It is consequently either feared or despised by many sound teachers who have not taken the trouble to understand itthough they often exemplify its teachings in their own practice. They think that the presence of interest implies pro tanto the absence of hard work and "discipline." In reality the presence of interest, properly understood, is the essential condition that hard work shall be profitable and "discipline" actual. It is interest alone that makes boy or man willing "to scorn delights and live laborious days."

For to appeal to interest is to touch the hidden springs of spontaneity; to release the energy that expresses itself in all purposeful activity. The critics of the doctrine constantly confound interest with pleasure. They do so because there still lurks in them either the receptacle-for-information view of teaching or the belief that education forms a mind by acting on it from without as the blacksmith moulds and tempers the iron. They think

1 The laws of commutation, distribution, etc.

2 Prof. Adams' "Herbartian Psychology" is an account of the doctrine of interest, which has already become an educational classic. 
that in some mysterious way either the knowledge or the "discipline" does the pupil good, and that "interest" must be mixed with them as jam is mixed with the powder-and for the same reason.

'I'he doctrine that school mathematics is to be an activity reproducing the essential features of historic mathematics is obviously not a "soft" doctrine. For hard and persistent effort as well as exact thinking are certainly among the essential features. But they are characteristics which are not imposed externally; they are the natural marks of intellectual activity when it pursues an end genuinely desired. It would be unreasonable to expect complete parallelism here between the boy and the mathematician. The mathematician selects his own goal and seeks it how he pleases; the boy much accept the choice of his teacher and must work under minutely prescribed conditions of time and place. Apart from his immaturity these differences imply that the internal forces must be supplemented by external influences. It remains true, however, that the boy's efforts are valuable to him only in proportion as they are spontaneous - that is, are the expression of a genuine impulse awakened by an object that really appeals to him.

Misunderstanding on these matters is fatally easy. At the risk of tedium it must be explained that spontaneity does not necessarily mean invention. I show spontaneity in reciting one of Wordsworth's sonnets or in playing a nocturne by Chopin if only I "put myself into it." That is, I can use the words of the poet or the musician's melodies as a means of self-expression. This observation has an important bearing on the question of "mental discipline." The discipline involved in learning mathematics is, ultimately, the boy's attempt to improve his powers by assimilating the methods of the great performers. It is the 'prentice's striving after the touch of the mastercraftsman. In due measure this "formal "element must always be present in an activity which seeks to reproduce actual mathematics. But it must be present as an expression of spontaneity. The purposeless manipulation of symbols has no claim to disciplinary value.

\$9. Summary. Finally it should be urged that the view of algebra teaching bere defended is not only sound in itself, but also includes what is sound in views which, as they are commonly held, must be rejected. Thus, on the one hand, it gives due place to the formal or "disciplinary" elements in mathematics; for these are essential features of the historic activity. And, on the other hand, it guarantees the usefulness of the instruction to those who are to enter mathematical professions. For algebra in the utilitarian stage is to be presented not as a gymnastic manipulation of symbols but as an attempt to understand, and so (in due measure) to control the phenomena of nature and society. Taught in this way, the young engineer should not so often find it difficult to see the connexion between the symbolism of his text-book and the behaviour of his machines. The mathematical specialist should not grow into the state of the Senior Wranglers described by Sir J. J. Thonson, who on entering a physical laboratory "are astonished to find that their formulae are true"; while the general body of boys and girls, who will not make direct applications of their mathematical studies in after-life, should cease to regard algebra merely as a "subject" imposed upon them by the caprice of teachers or examiners, and should gain some appreciation of the part it plays in forwarding important human concerns.

T. P. NunN.

\section{THE THEORY OF ORDER, AS DEFINED BY BOUNDARIES.}

\section{Unique Collations.}

So much for preliminaries. We come now to the formulation of a postulate which may be compared to Euclid's "Let it be granted that 